\title{
Levende billeder på nettet
}

\author{
Af Mikkel Weider
}

Siden slutningen af 90'erne har verden oplevet en eksplosiv udvikling i mangden af videoklip på Internettet. Fra at vare et overvejende tekst- og grafikbaseret medie, har Internettet udviklet sig til også at have betydelige mangder levende billeder. En lang rakke hjemmesider har allerede implementeret, eller planlagger at implementere, levende billeder i form af live transmissioner og video-on-demand. Derved skabes en slags hybrid mellem de typisk tekstbaserede hjemmesider og det traditionelle tv-medie. Det er denne artikels fokus at beskrive saregenhederne for den nye mediehybrid.

\section{Et forjattet land}

I årevis har tv-producere, forskere og journalister talt om begrebet interaktivt-tv. Tv hvor brugerne selv vælger sendetidspunkt og hvilke programmer de vil se, og hvor seerne ikke længere blot følger passivt med, men aktivt interagerer med indholdet i tv-programmerne. Revolutionen inden for det traditionelle tv-medium har dog ladet vente på sig. Til gengæld har opblomstringen af Internettet pludselig betydet, at det forjættede land måske ikke er så fjernt endda. På Internettet kan man ikke bare få near-video-on-demand, men truevideo-on-demand. På Internettet kan de levende billeder implementeres $\mathrm{i}$ en større multimedie kontekst, hvor tekst, chat, grafik, tv og spil går op i en højere enhed. På Internettet kan man ikke bare pause og spole i tv-programmerne, men også navigere $\mathrm{i}$ indholdet, og på anden vis lege sin egen producer, i hvert fald i teorien.

Men hvorfor er web-tv så ikke mere udbredt? Akilleshælen er teknikken. Den normale billedkvalitet er dårlig, billedudsnittet er lille, det tager lang tid at hente et klip frem og endelig koster det en ganske anseelig sum for webcasterne, hver gang brugere ser et videoklip (Christofferson \& Gatzke 2001). Disse forhold har bevirket, at flere web-castere allerede har måtte dreje nøglen om. For at overkomme de tekniske hindringer kræves bedre internetforbindelser og en mere effektiv komprimering af de levende billeder. Men selv om udviklingen her går hurtigt, er der dog stykke vej til at få den fulde broadcastkvalitet til den brede befolkning. I hvert fald hvis det skal være økonomisk forsvarligt.

\section{Fremtidens tv}

I forlængelse af ovenstående kunne man mene, at når først de tekniske og økonomiske hindringer er passeret, så vil web-tv udkonkurrere tv som vi kender det. Det er dog ikke min opfattelse. De to typer tv forekommer nemlig meget forskellige i deres brugsform. Receptionssituationen foran en pcskærm er anderledes end henslængt i en sofa foran en tv-skærm. Surfing på Internettet er typisk en meget utålmodig proces, der ikke egner sig til lange videoklip, og endelig er det også et spørgsmål om den normale tv-seer hele tiden ønsker en høj interaktionsfrekvens. Det er derfor min tese, at selvom vi oplever en netværkskonvergens, hvor tv og Internet distribueres af samme kanal, vil det traditionelle tv eksistere ved siden af web-tv, eller om man vil, pc-tv.

Formålet med denne artikel er derfor ikke at beskrive hele fremtidens tv-landskab, men at opridse konturerne af en ny type tv med egne regler og love. Det vil jeg gøre ved at slå ned på 4 elementer, der forekommer særligt nye i forhold til traditionelt tv. Disse fire aspekter er langt fra endegyldige kategorier, men karakteristiske særegenheder ved mediehybriden.

Gennemgangen er baseret på lige dele teoretiske overvejelser og lige dele empiri. De empiriske undersøgelser blev udført ved årsskiftet 2000/ 2001, i form af besøg hos 24 forskellige webcastere i fortrinsvis England og USA. Grundet denne artikels omfang og formål skal jeg dog ikke referere nævneværdigt til de konkrete undersøgelser, men primært opsummere konklusionerne fra min undersøgelse. 


\section{Interager med dit tv}

Muligheden for flervejs-kommunikation har betydet, at web-tv ofte er blevet sammenlignet med interaktivt tv, hvor brugerne på den ene eller anden måde interagerer med programindholdet. Men hvad dækker begrebet interaktivt tv egentlig over, og benytter webcasterne sig ret beset af mulighederne for interaktion?

En af de sidste par års mest benyttede typologier inden for interaktion har været Jan L. Bordewijk og Ben van Kaams kommunikations matrix. Denis McQuail, Poul Mayer og Jens F. Jensen er nogle af de forskere, der har argumenteret for brugen af de to telekommunikationseksperters terminologi (McQuail 1994: 56, Mayer 1998: 82, Jensen 1997 \& 99). Modellen må derfor formodes bekendt af Medie Kulturs læsere, og skal ikke forklares yderligere her (se bl.a. nr. 26 og 27). Indsættes karakteristika for web-tv i modellen ses følgende:
Ud over Bordewijk og Kaam har også andre teoretikere forsøgt at definere, hvad interaktive medier er. En af de mest betydningsfulde er Brenda Laurel. Laurel inddeler interaktivitetsbegrebet i et kontinuum karakteriseret af 3 variable (Laurel 1991: 20). 1: Hvor hyppigt kan brugeren interagere (Frekvens). 2: Hvor mange valg er til rådighed (Omfang). 3: Hvor meget valget påvirker forholdene (Indflydelse). En af de store fordele ved Laurels terminologi er muligheden for at gradbøje interaktionen. Man kan f.eks. beskrive konsultativt web-tv ved, at der typisk er et stort omfang af valgmuligheder, en vis frekvens, men en meget lille indflydelse fra brugernes side.

Med Laurels terminologi i baghovedet kan man bl.a. se nærmere på den type tv-programmer, der lancerer sig som interaktive ved at brugerne kan chatte med værterne. Denne form for kommunikation giver ifølge Laurels termer brugerne stor indflydelse på programmet, i og med at den enkelte

\begin{tabular}{|l|l|l|}
\hline & Center producerer information & Bruger producerer Information \\
\hline $\begin{array}{l}\text { Center }<>\text { kontrollerer } \\
\text { distribution }\end{array}$ & $\begin{array}{l}\text { Transmission } \\
* \text { Live web-tv } \\
* \text { Web-kameraer }\end{array}$ & $\begin{array}{l}\text { Registrering } \\
* \text { Afstemninger } \text { i forb. } \text { m. prog. }\end{array}$ \\
\hline $\begin{array}{l}\text { Bruger }<>\text { kontrollerer } \\
\text { distribution }\end{array}$ & $\begin{array}{l}\text { Konsultation } \\
* \text { Video On-demand } \\
* \text { Berøringsfølsomt tv }\end{array}$ & $\begin{array}{l}\text { Konversation } \\
* \text { Chat-med varten og brugerne }\end{array}$ \\
& $*$ Bruger-kontrolleret og produceret tv \\
\hline
\end{tabular}

I matrixen er indsat karakteristika for levende billeder på nettet, hvilket gerne skulle illustrere, at web-tv spreder sig over langt flere kommunikationsformer end traditionelt tv, der normalt er ren transmission.

Et vue over web-tv landskabet anno 2002 afslører en markant overvægt af det konsultative kommunikationsmønster, hvor interaktionen udmønter sig i, at brugerne kan vælge mellem forskellige videoklip. De andre kommunikationsformer har primært sekundære funktioner, f.eks. i form af chat og afstemninger i forbindelse med videoklippene. Derudover findes enkelte live transmitterede indslag. Der eksisterer tv-stationer, hvor brugerne laver programmerne, men de er i voldsomt undertal i forhold til store kommercielle broadcastere, hvilket bl.a. skyldes at tv er dyrt at producere og markedsføre. brugers input får indflydelse på, hvad der skal snakkes om i studiet. Til gengæld svinger omfanget og frekvensen af interaktionsmuligheder betydeligt. Det er nemlig langt fra sikkert, at brugerens spørgsmål besvares, og typisk er brugerens eneste interaktionsmulighed blot at stille flere spørgsmål. Det er derfor ikke altid lige hyppigt, at brugeren får lov til at udøve indflydelsen, hvilket vil sige, at frekvensen af interaktionsmulighederne er lav, og mange gange er der meget få forskellige interaktionsmuligheder, hvilket vil sige, at omfanget er begrænset. Ovennævnte problemer skyldes i høj grad, at indflydelsen i vid udstrækning er afhængig af, hvor mange der ser programmerne. Jo flere der ser programmerne, desto sværere bliver det at interagere. Denne form for interaktion vælger jeg at kalde »tilfældets interaktion«, hvilket fortæller, at man som bruger ikke kan være sikker på at få lov til at interagere. 
Et af de mest kendte eksempler herpå er nu hedengangne Pseudo. Pseudo var en af verdens første, og i et par år største, web-tv-station. Pseudo havde en række kanaler, hvor et af de mest essentielle aspekter var, at brugerne kunne chatte med værterne under programmerne. Pseudos indbyggede mulighed for at chatte med studieværten led tydeligt af, at jo flere der chattede med værten, desto sjældnere kunne værten svare på de enkelte kommentarer. Havde Pseudo derfor fået flere hundredetusinde brugere ville interaktivitets-niveauet have svaret til gammel-kendte formater som f.eks. radioprogrammet Strax på P3 eller tv-programmet 19-direkte på DR1. Dette harmonerede ekstremt dårligt med Pseudos forsøg på både at få så mange brugere som muligt, og at skabe meget interaktive miljøer. For at opretholde de mange brugere og den store interaktion oprettede Pseudo mange nye kanaler, men det blev lynhurtigt ekstremt ressourcekrævende, og da Internetaktierne i foråret 2000 begyndte at falde, måtte Pseudo få uger efter dreje nøglen om.

Konklusionen herpå er ikke, at brugerne ikke kan få indflydelse, men at det ikke er alle typer interaktion der er lukrative, og at web-tv derfor ikke nødvendigvis altid er ekstremt interaktivt. For en større broadcaster vil det som regel være en fordel at bevare en betydelig kontrol over distributionen og især produktionen af tv-programmer, og så kun implementere mere konverserende former for interaktion ved siden af.

\section{Time is on my side}

En anden særegenhed ved web-tv er tidsaspektet. Det faktum, at de fleste indslag ikke transmitteres, men kan konsulteres on-demand betyder, at brugerne, i modsætning til traditionelt tv, kan se programmerne, når det passer dem. Traditionelt set er det tv-stationen, der bestemmer, hvornår et givent program skal vises. De dyreste programmer vises f.eks. i primetime, og man forsøger at få seerne til at hænge på ved at tilrettelægge et flow, der skal skabe en sammenhængende tv-oplevelse. I web-tv er »primetime - my time«, og programmerne flyder ikke over i hinanden, men opleves fragmentarisk.

F.eks. er det ikke sikkert, at det passer mig at se nyhederne kl. 19 eller 21, og det er heller ikke sikkert, at jeg synes alle nyheder er seværdige nok. Når nyhedsindslagene derfor ligger on-demand kan jeg konsultere dem når som helst, og jeg kan nøjes med at se de indslag, der interesserer mig. Jeg har med andre ord overtaget kontrollen over distributionen af informationer, og skal aktivt tilvælge programmer når jeg ser tv. Denne form for aktivt tilvalg har selvfølgelig stor betydning for hvilke programmer jeg vælger, og selvom web-tvfeltet må betegnes som forholdsvist nyt, forekommer det allerede at have stor indflydelse på hvilke programmer der udbydes.

De programmer der anno 2002 udbydes mest lægger sig i to lejre. De programmer der er meget aktuelle, og de programmer der er meget langtidsholdbare. Mellemgruppen er nærmest ikke eksisterende. De meget aktuelle indslag spiller på Internettets mulighed for at være et nu-og-her nyhedsmedie, hvor man kan blive opdateret når som helt på døgnet, og ikke først når det passer ind i en given nyhedsudsendelse. De meget langtidsholdbare programmer spiller til gengæld på Internettets mulighed for at være et database medie. Ved at lægge indslagene ud on-demand kan web-casterne over tid opbygge en stor seermængde, som illustreret nedenfor:

Antal samtidige brugere

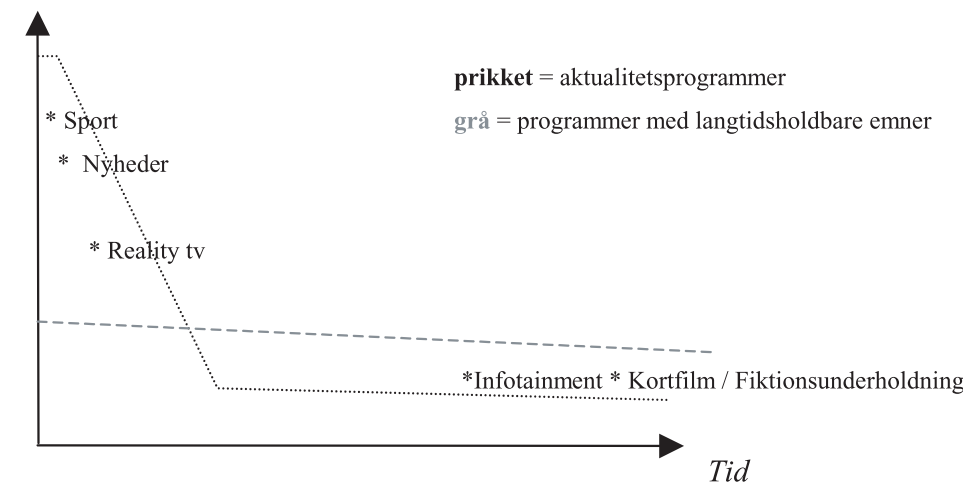


Grafen illustrerer, hvordan de langtidsholdbare emner, på trods af færre samtidige brugere, over tid kan få mange brugere. Sport tiltrækker typisk et enormt publikum i forbindelse med live begivenheder, men til gengæld falder interessen drastisk efter begivenhedens afslutning. Infotainment kan derimod opleve en stabil popularitet over mange måneder, hvilket i sidste ende kan betyde ganske anseelige seertal.

Konklusionen herpå er derfor, at begreber som primetime og flow ikke længere har samme betydning, og at programplanlægningen mere er et spørgsmål om at skabe nogle programmiljøer frem for programflader. Derudover påvirker tidsaspektet også programmernes emnevalg, hvilket vi skal se nærmere på i det følgende.

\section{Mit tv - om mine interesser}

Medieforsker John Ellis har i Seeing Things beskrevet udviklingen af tv-mediet fra fødsel til digital tv. Ellis inddeler tv's historie i tre overordnede perioder: »the age of scarcity«, »the age of availability« og »the age of plenty« (Ellis 2000). »Age of scarcity« er den periode, hvor en eller få store broadcastere sendte brede programmer til familien i primetime. En periode hvor seernes valgmuligheder var at slukke eller tænde for DR, og hvor man kunne stille spørgsmålet: »Så du fjernsyn i går?«. I »Age of availability « er antallet af kanaler udvidet markant, og man stiller i stedet spørgsmålet: »Så du det særlige program på den og den kanal?«. En lang række tv-kanaler sender udelukkende til særlige målgrupper eller inden for særlige emneområder, og seernes valgmuligheder er blevet markant flere. Tv anno årtusindeskiftet befinder sig, ifølge Ellis, i denne periode, men er hastigt på vej mod den næste: »Age of plenty«. Brugerne vil, i denne fremtidige mangfoldighedens tidsalder, konsultere tusindvis af programmer om alle mulige emner skræddersyet til brugernes særlige behov. Tv er ikke længere blot tv, og: »I går gjorde jeg dette og hint med mit tv«.

Ser man med web-tv øjne på Ellis' sondringer er det tydeligt, at web-tv tilhører the age of plenty, i og med at web-tv kan tilbyde tusindvis af programmer og ægte video-on-demand. En af konsekvenserne heraf er ifølge Ellis, at »broadcasterne« i højere og højere grad vil begynde at narrowcaste i erkendelse af, at de ikke kan nå de store brede mængder, men derimod de mindre, men veldefinerede målgrupper. Ellis beskriver i denne forbindelse det moderne tv som: »a much more diverse consumer market, which accentuates and commodifies every available difference between citizens in the name of choice.«(Ellis 2000: 2). Og I forlængelse heraf mener han, at man i fremtiden vil se et boom af smalle, specialiserede emner.

På nettet kan man se indslag om alt fra avanceret bukkejagt til 100 måder at bage brød på, og der er mange af dem. Denne type programmer ville man normalt aldrig se på traditionelt tv, men på nettet har de fået en opblomstring. Dette må skyldes flere aspekter: For det første betyder muligheden for at lagre programmerne on-demand, at selv smalle emner på sigt kan opleve betydelige seertal. For det andet er Internettet et globalt medium, hvilket betyder, at alle med en Internetforbindelse i teorien vil kunne se dit indslag, og ikke som nu, hvor seermængden er bundet til geografi og programpakke. Dette aspekt er især vigtigt for engelske og spanske webcastere, i og med at de vil kunne appellere til deres målgruppe i en lang række lande, og på den måde opnå høje seertal. For det tredje er det i høj grad nødvendigt for webcastere at positionere sig $\mathrm{i}$ forhold til hundredevis af andre webcastere, og det gøres i vid udstrækning ved at specialisere sig inden for særlige brands og interesseområder.

Disse faktorer afspejles da også i dagens webtv-landskab, hvor web-castere, der blindt har forsøgt at kopiere det traditionelle tv, næsten alle har måtte bukke under, hvorimod web-castere, med målrettede programmer til specifikke målgrupper, har haft lettere ved at blive markedsledende, og derfor lettere ved at overleve. Forskeren Tatsuhito Nagaya har ligefrem argumenteret for, at man i fremtiden vil se decideret personalcasting, hvor programmer, om ikke er lavet til, så i hvert fald er skræddersyet til, den enkelte seer (Nagaya 1997: 183). Denne tendens kender vi også fra andre steder på Internettet, hvor man f.eks. kan få skræddersyede nyhedsbreve. Selv om disse personaliserede services ikke er helt så udbredte inden for web-tv, er det dog oplagt, at man i fremtiden vil se mange flere eksempler herpå. Et scenarie inden for personaliseringen er, at programmerne i stigende grad vil centrere sig om kommercielt interessante emner. Herom skrev internetguru Nicholas Negroponte helt tilbage i 1995:

As media companies go more and more toward narrowcasting, like the magazine business, they are still pushing bits at a special-interest group, 
like car fanatics, alpine skiers, or wine enthusiasts ... The information industry will become more of a boutique business. (Negroponte 1995: 84-85).

På trods af at citatet er ved at have nogle år på bagen, forekommer det mere relevant end nogensinde før. I takt med web-tvs udbredelse og de økonomiske problemer i Internetbranchen er webcasterne i stor stil begyndt at indrette indholdet efter emner, der er kommercielt interessante. Og et muligt fremtidsscenarium for web-tv er, at mange af kanalerne på sigt vil blive til avancerede former for tv-shops. I modsætning til nu vil der dog være tale om tv-shopping ud fra mine præferencer og mine interesser.

Kommercielt eller ej, web-tv forekommer at være langt mere individuelt end traditionelt tv. Web-tv lægger i sin receptionsform ikke op til, at der skabes fællesskab foran pc-skærmen, men snarere online communities »bag pc-skærmen« i veldefinerede interessegrupper.

\section{Mange medier i ét}

Et fjerde vigtigt område, hvor web-tv for alvor adskiller sig fra traditionelt $t v$, er gennem Internettets funktion som multimedium. Hvor traditionelt tv normalt kun kan implementere simple former for tekst og grafik, kan web-tv integreres i en større helhed af tekst, billeder, grafik, chatfora osv. Viser en web-caster f.eks. et madprogram kan de sammen med selve videosignalet vise opskrifter, billeder og hjælpende tips. De kan også lade brugerne bestille varerne online eller måske svare på uddybende spørgsmål. Endelig kan brugerne opleve det hele i deres eget tempo. Web-tv er med andre ord meget mere end tv, og nogle gange vil tv-elementet spille en sekundær eller tertiær rolle. Derfor vil man typisk heller ikke kalde alle services, der viser video på nettet, for web-tv.

Umiddelbart kunne man foranlediges til at tro, at narrowcasterne pga. deres smallere fokus ville gå yderligere i dybden med indholdet i form af en omfattende brugerflade, og at det modsatte ville være gældende for broadcasterne. Men dette er ikke tilfældet. Et glimrende eksempel herpå er f.eks. CNN, der på trods af en meget bred brugerskare, dedikerede en hel sektion med titlen »Denmark decides« til den danske ømu-afstemning udover talrige programindslag om emnet. I sektionen kunne man bl.a. se kort, billedarkiv, vox-pop, po- litikerportrætter og quizzer, hvilket i højeste grad må betegnes som at gå i dybden med et emne vha. en omfattende brugerflade.

Et kig på web-tv-landskabet viser, at det især er nyheder, sport og infotainment der bruger store programbrugerflader. Fælles for de tre genrer er, at folk typisk har særlige interesser inden for særlige områder, som han/hun gerne vil gå i dybden med. F.eks. er det oplagt, at den nyhedsinteresserede kan se kort og grafer inden for personens interesseområder, og så blot skimme de nyheder, der ikke har samme interesse. Det er også oplagt, at den sportsinteresserede, udover at se et program, kan læse resultater og artikler inden for en given sportsgren, samt kommunikere med ligesindede. Endelig er det oplagt, at lystfiskeren, bilentusiasten, modefreaken og de andre infotainmentseere kan diskutere, researche og handle inden for deres respektive interesseområder.

Især muligheden for at knytte programvirksomhed med handel er en ny og interessant mulighed for tv-stationer. Når en typisk tv-seer ser en reklame for en bog må han/hun normalt vente til næste dag med at købe den, og handlen vil som oftest foregå et helt andet sted. Når brugerne på nettet derimod ser en reklame vil de, optimalt set, kunne bestille varen med det samme. Pga. Internettets status som multimedium kan programmer og fysiske produkter derfor knyttes meget tæt sammen, hvilket på sigt kan blive meget lukrativt for web-casterne. At web-tv derfor er meget mere end blot tv åbner op for en lang række nye muligheder for både kommercielle og non-kommercielle webcastere, og selv om det er de færreste web-castere der i dag bruger disse muligheder til fulde, vil det på sigt få stor indflydelse på tv-landskabet.

\section{Brugertid}

Nu har jeg opridset nogle overordnede særegenheder for web-tv i forhold til traditionelt tv. Fælles for disse særegenheder er, at de skaber en merværdi i forhold til traditionelt tv. Web-tv tilbyder flere forskellige former for kommunikation, mere interaktion, større udbud af programmer og dækker flere områder. På traditionelt tv får den lidt interesserede seer og den meget interesserede seer præcis samme inputs, hvorimod den interesserede seer af web-tv i teorien kan se flere timers materiale om det pågældende emne. Web-tv giver med andre ord brugerne mulighed for at blive serviceret på langt flere niveauer, hvilket grafisk kan illustreres som i følgende graf. 


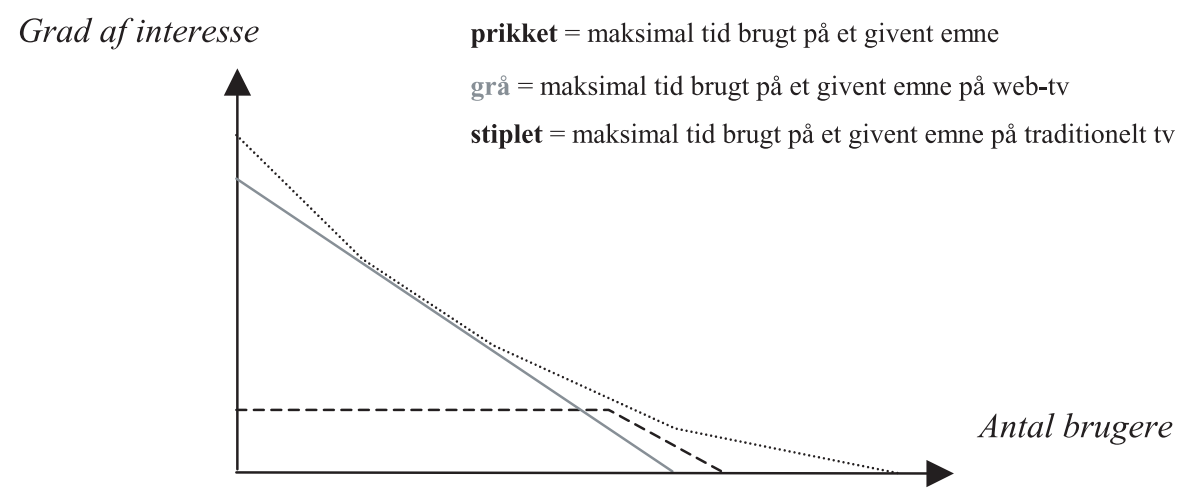

Grafen læses således, at arealet afgrænset af den sorte kurve udgør den samlede seer-interesse, hvilket lidt groft kan sammenstilles med det samlede antal minutter/timer der potentielt set kan bruges på et givent emne. Arealet afgrænset af den grå kurve er på denne led det samlede antal minutter/ timer brugerne potentielt set kan bruge på emnet via web-tv. Jo større arealet er, desto mere tid tilbringer brugerne hos web-casteren. Som det gerne skulle fremgå, er der altså en forholdsvis lav max-grænse for, hvor meget tid den engagerede bruger kan bruge på et traditionelt tv-program, i forhold til web-tv, hvor max-grænsen kan være ekstremt høj. Det skal hertil bemærkes, at grafen ikke giver et reelt billede af den aktuelle tv-situation, hvor brugerne nemlig ser meget mere tv end web-tv. Grafen skal derfor mere opfattes som en illustration af web-tv's potentielle muligheder. Essensen ved grafen er, at man som web-caster ikke nødvendigvis bør konkurrere med tv om at sende programmer til så mange som muligt, men i stedet satse på at holde de seere man har i så lang tid som muligt, ved at servicere dem efter behov. Fordelen herved er, at de seere, der er meget interesserede, vil blive eksponeret for mange forskellige reklamer og shoppingmuligheder, hvor imod de mindre interesserede vil se færre reklamer og være mindre tilbøjelige til at handle. Denne reklameform egner sig derfor specielt godt til reklamer for målrettede produkter, således at børnefamilier ser reklamer for bleer, og pensionister ser reklamer for ældresagens rejser, og ikke omvendt.

\section{At maksimere brugertiden}

Men hvordan servicerer web-casterne så bedst brugerne efter behov, således at den samlede bru- gertid maksimeres? Det er min opfattelse, at webcasterne i høj grad bør satse på at lave omfattende brugerflader som brugeren kan gå i dybden med. Dog bør web-casterne kun gå så tilpas grundigt til værks som de respektive genrer tillader. Overproducerer web-casteren programmer, tekst, billeder og grafik, således at web-casteren placerer sig uden for den grå eller sorte kurve i den tidligere opstillede graf, bliver produktionen typisk for dyr. Som landet ligger pro tempore er det endvidere min opfattelse, at en vis fokusering på smalle emner med engagerede brugere vil give en længere samlet brugertid, bl.a. fordi web-tv ikke kan konkurrere med traditionelt tv på traditionelt tv's præmisser. Endelig er det min opfattelse, at web-casterne via langtidsholdbare emner kan maksimere den samlede brugertid.

Interaktion forekommer også at være en særdeles vigtig brik i maksimeringen af brugertiden. Ved at give brugeren kontrollen over distributionen af informationer kan brugeren selv bestemme, hvor lang tid han/hun vil bruge på web-tv-stationen. I forlængelse heraf er det nødvendigt med stort omfang, og evt. en vis frekvens, af valgmuligheder, således at brugeren ikke forlader web-casteren, fordi der er for lidt materiale. På denne led serviceres både de brugere, der er meget interesserede og de brugere, der kun er lidt interesserede, som illustreret ved den grå kurve i grafen. For at kunne maksimere tiden er det endvidere nødvendigt at vide, hvilke præferencer brugerne har. På baggrund af f.eks. bruger-statistik og rating-systemer (registrering) er det muligt at indrette indholdet efter hvad der er populært, og ved at involvere brugerne i selv at producere eller kommunikere (konversation) kan brugerne være med til at lægge niveauet for interessen. Som påpeget tidligere kan visse typer 
interaktion dog være problematiske, fordi brugeren ikke altid er garanteret indflydelse, hvilket kan resultere i en kortere brugertid.

En anden måde hvorpå man kan maksimere brugertiden, udfra mere økonomiske perspektiver, er ved at genbruge programmaterialet så meget som overhovedet muligt. Ved at vise programmerne i et større netvark af hjemmesider kan den samlede brugertid nemlig maksimeres. F.eks. kan man forestille sig et samarbejde mellem en portal, der henvender sig til et større men ikke specielt interesseret publikum, og en web-caster, der henvender sig til et mindre men meget interesseret publikum. På denne led serviceres nogle brugere i dybden og andre i bredden, hvilket betyder, at den samlede brugertid, på tværs af forskellige platforme, bliver større.

\section{Afrunding}

Jeg har i denne artikel fokuseret på nogle muligheder for web-tv, som er radikalt anderledes end mulighederne for det traditionelle tv-medie. Og man kunne i forlængelse heraf spørge sig selv om ikke web-tv er fremtidens tv?

Ser man tilbage på tidligere medier er det dog bemærkelsesværdigt, hvor gode overlevelsesevner de eksisterende medier har haft, og kun i meget særlige tilfælde har et medie fuldstændigt overtaget et andet medies karakteristika (Jf. bl.a. Rasmussen 1999: 152). I forlængelse heraf, og på baggrund af min tidligere argumentation, er min tese, at web-tv og tv er to meget forskellige medieformer, hvorfor web-tv ikke bare vil udkonkurrere traditionelt tv når bredbåndet udbredes. Selv hvis medierne konvergerer er det min opfattelse, at man i fremtiden vil have flere typer tv afhængigt af receptionssituationen. Tv set på en tv-skærm vil primært være egnet til underholdning, fiktion, transmission af nationale begivenheder og programmer, der generelt fordrer en mere indlevende, passiv eller social reception. Tv set på en pc vil derimod være egnet til informative genrer som f.eks. specifikke nyheder, infotainment og programmer, der generelt passer til den aktive og individuelle brug, computeren fordrer.

Som web-tv-landet ligger i dag er det min overbevisning, at de fleste web-castere langt fra er gode nok til at udnytte mediehybridens muligheder. Web-casterne sender typisk for dårlige programmer om for mange emner uden at implementere resten af brugerfladen godt nok. Jo flere medier og jo mere web-tv der kommer i fremtiden, desto mere kamp bliver der om brugernes tid, og desto mere målrettede skal web-casterne være. Der vil derfor ikke være plads til web-castere, som spilder brugernes tid, eller som ikke formår at holde på deres brugere, så brugerne »spilder« deres tid andetsteds. I forlængelse heraf vil fremtidens førende web-castere være de selskaber, der bedst formår at målrette deres indhold, kommunikation og finansiering efter web-tv-brugernes særlige behov og ønsker.

\section{Litteratur}

Bordewijk, Jan L. \& Ben van Kaam (1986): »Towards a new classification of TeleInformation Services« in: InterMedia, januar 1986, vol. 14, nr. 1. International Institute of Communication.

Christofferson, Scot A. and Michael A. Gatzke (2001): "Broadband media: Look before you leap« in: The McKinsey Quaterly, 2001 no. 4 (www. mckinseyquarterly.com).

Ellis, John (2000): Seeing Things - Television in the Age of Uncertainty, I.B.Tauris Publishers, New York.

Graham, Andrew (1999): »Broadcasting Policy in the Multimedia Age« in: Public Purposes in Broadcasting - Funding the BBC, University of Luton Press, Luton.

Jensen, Jens F. (1997): »Interaktivtiet - på sporet af et nyt begreb i medie og kommunikationsvidenskaberne«, in: Mediekultur nr. 26, Aalborg Universitetsforlag, Aalborg.

Jensen, Jens F. (1997): »Vejkort til informationsmotorvejen«, in: Mediekultur nr. 27, Aalborg Universitetsforlag, Aalborg.

Jensen, Jens. F (1999): »The Concept of Interactivity«, in Interactive Television, TV of the Future or the Future of Television?, Aalborg Universitetsforlag, Aalborg.

Laurel, Brenda (1991): Computers as Theatre, Addison-Wesley, Reading.

Mayer, Paul A. (1998): A Social Semiotic Approach to the Analysis of Computer Media, Department of Film and Media Studies, University of Copenhagen.

McQuail, Denis (1994): Mass Communication Theory, Sage, London.

Nagaya, Tatsuhito (1997): The Evolution toward Multimediatype Television - Viewers' Selction and ISTV, BCRI, Nippon Hoso Kyokai.

Negroponte, Nicholas (1995): Being Digital, Vintage Books, New York.

Rasmussen, Terje (1999): »New media Change«, in: Interactive Television, TV of the Future or the Future of Television?, Aalborg Universitetsforlag, Aalborg.

Mikkel Weider er redaktør på TV 2 Interaktiv og ekstern lektor ved Institut for Film- og Medievidenskab, Københavns Universitet. 